mr. sc. Faruk Hadžić, Lecturer ${ }^{1}$

\title{
THE IMPORTANCE OF TECHNOLOGICAL PROGRESS IN MEASURING ECONOMIC GROWTH IN BOSNIA AND HERZEGOVINA
}

\begin{abstract}
Economic growth is one of the most important concepts in the world economy. Although some authors critically believe that the level and rates of economic growth do not necessarily reflect the actual standard of living, it stiIl remains the main way to measure a country's well-being. Different views on the topic of economic growth, as well as the factors that influence it, have been present throughout the history of economic thought from the very beginning. Unlike many theories of economic growth, which believe that in the long run there will be diminishing returns on factors of production such as labor and capital, Paul Romer in his theory of endogenous growth believes that technological progress, through knowledge accumulation, idea creation and innovation, leads to increasing returns, and thus contributes more to long-term economic growth, unlike other factors. In this paper, on the example of economic growth in $B \& H$, the hypothesis that the activities of knowledge-based services contribute more to the gross domestic product, compared to other sectors was tested. To prove the hypothesis, a multiple linear regression model was made based on a time series of 48 consecutive quarterly values of $B \& H$ gross domestic product and sectoral gross value added according to the income and production approach. In the model, activities were grouped into those that are predominantly labor-intensive, knowledge-based services, personal and social services, and other activities.

The results showed that the average value of gross value added per worker employed in the sectors of knowledge-based services has a 2.5 higher contribution compared to a worker in the labour-intensive sectors and a 2.47 higher contribution compared to one worker in the personal and social services segment. Also, tests of the implemented model show that additional employment in the sectors of knowledge-based services leads to accelerated economic growth in $B \& H$.
\end{abstract}

Key words: Economic Growth, Technological progress, GDP, Romer model, Endogenous growth theory

JEL: $032,047$.

1 Sarajevo School of Science and Technology, e-mail: farukhadzic27@gmail.com 


\section{INTRODUCTION}

Economic growth is one of the most important concepts in the world economy. Although some authors critically believe that the level and rates of economic growth do not necessarily reflect the actual standard of living, it still remains the main way to measure a country's well-being.

Different views on the topic of economic growth, as well as the factors that influence it, have been present throughout the history of economic thought from the very beginning.

The classics considered that the determinants of economic growth were investment and improvement of production capacities. In the early twentieth century, representatives of the neoclassical economy identified three factors of economic growth: land, labour, and capital, which were sufficient to explain the causes of economic growth in capitalist countries. The more these factors were used, the higher the growth. Adam Smith and David Ricardo determined economic growth by production, supporting Say's "Law of Market". According to Adam Smith, an increase in production will affect the size of the market in terms of increase, thus placing emphasis on supply economy. Marx had similar views on the role of supply, but disagreed with Say's "Law of Market." According to him, if there is a crisis of hyperproduction in the economy, then the thesis that supply generates its demand has no basis.

The classics also had different views on the productivity of the factors of production. Unlike Smith, who assumed rising yields, Malthus and Ricardo assumed declining yields on factors entering the production process.

Smith was also the originator of the concept of division of labor as a major factor in economic growth. According to Smith, the division of labor is the result of the accumulation of capital and the gradual expansion of the market. He also considered the positive role of technological innovation in the process of economic growth.

Unlike the classics, for whom economic growth is linked to supply, Keynes viewed demand as a factor of economic growth. He did not accept Say's "Law of Market" believing that the economic mechanism by its nature tends to imbalance and unemployment. In his model, in the short run, the main factor of economic growth is investment.

Theories of economic growth have tried to offer an answer as to which factors influence economic growth. In his theory (Malthus, 1798), Malthus held that throughout human history, technological advances had led to an increase in population, but had no effect on per capita income in the long run. 
In the time of classical economics, theories of production and theories of growth were based on the law of variable relations, where an increase in one of the factors of production (labour or capital), assuming constant other conditions, will lead to output growth, but under declining yields, eventually reach a value of zero (Bjork, 1999).

In his work, Solow (Solow, 1957) expressed the share of land, capital, and labour in U.S. economic growth, emphasizing diminishing returns on labor and capital. Capital is raised through investment, but the level decreases due to falling values. Due to diminishing returns on capital, with an increase in capital and the number of workers, and in the absence of technological progress, output per worker remains constant because investments in capital are equal to the annual decrease in the value of capital.

If the growth is based on technological progress, then that growth will be sustainable in the long run as Solow and Swan claim. On the other hand, if economic growth is generated from the factor of production, due to the growth of labor or capital inputs, it will be temporary, because when the capital-labour ratio is stable, diminishing returns occur (Solow 1956, Swan 1956 ). According to this model, technological progress is key to long-term economic growth. However, this model does not explain how technological progress is being made. Because this model cannot explain how technological progress occurs, it is also called the exogenous economic model of growth.

Since the Solow-Swan model did not explain how technological progress occurs, Paul Romer developed a model that explains how technological progress occurs. The Romer model of growth (Romer 1986) is also another model of endogenous growth and is part of new theories of growth. Compared to other theories, Romer believes that there is a growing return to the scale of the entire economy. This model is based more on microeconomic foundations, unlike the Solow-Swan model. According to the model, the accumulation of knowledge is key to economic growth, because the discovery of new knowledge enables companies to produce better and more productive capital goods. One important critical aspect of this model is the assumption that knowledge is external. New knowledge cannot be hidden in full and it spills over to other companies. Because of this, companies conduct too little research because they hope to benefit from research conducted by other companies. Romer believed that accumulated knowledge and specialization were key to economic growth. According to him, the increase in the number of inhabitants will not lead to an increase in knowledge, but human capital that is trained to create new ideas.

Given that the authors of other growth theories believe that in the long run there will be declining returns on engaged factors of production (labor and capital), in contrast to Romero's model, where technological progress, through knowledge accumulation, idea creation and innovation, leads to increasing returns. 


\section{Review of Relevant Literature}

In the domestic literature, it is possible to find papers that analyze the role of innovation and / or accumulation of knowledge on the growth of small and medium enterprises. On the other hand, there were no papers available where the authors tested the models of economic growth on the example of Bosnia and Herzegovina, so it is also a shortcoming to compare the results. The same is true for the countries of the region.

In his work (Stevanović, 2019), he dealt with the problem of whether the economy of $\mathrm{B} \& \mathrm{H}$ is in balance, and in which way the equilibrium state is determined and the stability and balance of the system can be achieved. He further researched the production function of $\mathrm{B} \& \mathrm{H}$, potential GDP trends and deviations in nominal GDP trends from potential ones.

In one paper from Croatia, Moore and Vamvakidis (Moore \& Vamvakidis, 2008) examined the factors and constraints that affect current and potential growth in Croatia, as well as the policies that may affect it.

According to neoclassical theory, long-term economic growth is due to an increase in exogenous factors such as an increased workforce or technological progress. The country's export growth strategy aims to provide incentives for the export of goods through various economic policy measures. Its goal is to increase the production of goods and services that can compete in the global market, use advanced technology and provide foreign exchange earnings needed to import capital goods. The emergence of new theoretical models that emphasize the importance of endogenous factors for economic growth has enabled the inclusion of foreign direct investment in the analysis as one of the determinants of growth (Franc, 2017).

When it comes to foreign literature, there are many papers dealing with this topic, mostly of more recent date, which will be presented below.

In their work, Cho \& Yi examined the impact of the Internet on the relationship between R\&D expenditure and economic growth. Data are presented for 105 countries in the period 1994-2014. They concluded that the impact of R\&D expenditures on economic growth had a positive effect on the Internet segment, and the effect of the Internet on economic growth was positively strengthened by an increase in R\&D expenditures (Choi \& Yi, 2018).

Furukawa explores the place of innovation in the world economy, where research and development (R\&D) of companies from different countries are involved in a joint innovation project. By advancing the standard model of growth based on research and development (R\&D), this paper finds two important factors of innovation through global collaboration: (i) whether global innovation finds its place through collaboration or outsourcing depends on relative productivity between global and 
local innovations. If global innovation is created through collaboration (ii), the level of global innovation depends on the relative contribution of skilled labor between economies (Furukawa, 2016).

In their work, Bondarev \& Greiner combine horizontal and vertical innovations to create an endogenous growth model that enables structural change as an endogenous phenomenon. Older technologies are continuously being replaced by newer ones due to creative destruction, and new technologies are emerging as a result of horizontal innovation and due to consumer preference for diversity. Each industry is profitable only for a limited period of time, making the effective time of technology existence endogenous and finite. This paper considers that in such an economy endogenous structural change is a source of constant economic growth. Furthermore, the range of existing sectors as well as growth rates remain constant as long as technologies are symmetrical (Bondarev \& Greiner, 2017).

Using a vector panel auto-regression model, Pradhan and colleagues studied the interactions between innovation, financial development, and economic growth in $18 \mathrm{eu}-$ rozone countries between 1961 and 2013. They focused on whether causality moves between these variables in both ways, in one way, in another way, or in neither. Their empirical results show that financial sector development and improved innovation capacity in the euro area contribute to long-term economic growth in countries in the region (Pradhan et al, 2016).

An interesting research was done by He. He studied the potential for rational bubbles in the innovation sector for long-term economic growth. He showed that stock prices for R\&D companies can include a bubble component when credit constraints are present. The bubbles are self-sustaining in equilibrium against the "liquidity" premium that arises when credit constraints are eased again. Balloons expand the borrowing and production capacity of R\&D companies, stimulate innovation and increase the growth rate. Unlike Hiran and Yanagawa (Restud, 2017), in his model: (i) balloons are included as part of the stock price rather than as value for otherwise unproductive assets; (ii) bubbles can occur at any level of financial development. Finally, it showed that balloons can create lasting effects that are beneficial to the innovation sector compared to other sectors (He, 2018).

In his work, Jerbashian modeled the licensing of knowledge (patents) and assessed the regulation of intellectual property in an endogenous growth framework where the driver of growth is internal research and development by high-tech firms. $\mathrm{He}$ showed that companies dealing with high technology innovate more, and economic growth is higher when there is licensing of knowledge and when the regulation of intellectual property facilitates the exclusion of knowledge, than when knowledge is not exclusive and there is a spillover of knowledge among high-tech companies. 
However, the number of high-tech firms is lower, and welfare is not necessarily greater when there is knowledge licensing than when there is knowledge spillover (Jerbashian, 2016).

In his paper, Qain examines the effect of patent protection in an endogenous growth model with a generic innovation process. It indicates that increasing the breadth of a patent encourages innovation when research and development is less intensive than production (Qian, 2018).

Although innovation has long been considered a key driver of economic growth, there is no commonly accepted standard by which we measure innovative activity. Therefore, Zhong applied a comprehensive variable, the Innovation Index 2.0, in his paper, which includes most of the measurements of innovative activities used in the literature. Using this index and its sub-indices, we are able to thoroughly examine how they are related to total personal income and population growth as intermediaries of economic growth. Another contribution of his work is to focus on smaller businesses, American counties, which have not been popularly studied in the literature. The results of the regression show that innovation, like most of its measures, contributes to income and population growth in U.S. counties (Zhong, 2017).

In their paper, Ghiglino et al proposed a model of unbalanced endogenous growth in which the final product can be consumed or used as capital. According to the authors, the final product is created using two indirect inputs, one of which is "knowledge-intensive". Agents working in the knowledge-intensive sector must accumulate technological knowledge and therefore must decide how to divide their individual unit of time between the accumulation of technological knowledge (research) and work. Agents working in another sector do not have to accumulate knowledge and thus dedicate their entire individual unit of time to work. Individual knowledge becomes a factor in increasing the workforce, and the accumulation of knowledge leads to an unlimited increase in TFP in the intensive knowledge sector, and thus to a deepening of endogenous capital. Asymmetry in TFP growth rates leads to unbalanced growth. There is a redistribution of labor (number of workers) in different sectors, which further leads to an increase in production in the knowledge-intensive sector. They have shown that disproportionate growth is in line with the Kaldor facts, as the asymptotic equilibrium is primarily marked by a constant interest rate and the share of capital in national income. However, the economy follows a path of growth that approaches a certain level of wealth that depends on the initial cost of capital and knowledge. As a consequence, countries with the same bases but lower initial wealth will be characterized by lower asymptotic wealth (Ghiglino et al, 2018).

It is widely accepted by theoretical and empirical economists that growth and fluctuations are two sides of a unique dynamic evolution of economics, which must 
be studied with identical analytical tools and techniques. Business cycle theory and growth theory use the same type of dynamic models of general equilibrium and share statistical and econometric procedures. However, unlike business cycle models, in which calibration and simulation have a long and successful tradition, growth models have hardly applied these interesting and fruitful techniques. Gutierrez's work overcomes this specificity by designing Romer's fully specified endogenous growth model, fully micro-based, which translates into an AK model that is amenable to calibration and simulation and that allows stylized growth facts to be explained. When applied to the U.S. economy, the proposed model provides a good fit into empirical data (Gutierrez, 2015).

In his paper, Zhao discussed how technology is integrated into the study of economic growth. He focused on Romero's endogenous theory of growth, for which he received the Nobel Prize in Economics in 2018 (Zhao, 2019).

In his work, Sredojević and his associates analyzed the issue of treating the category of technological changes within the main aspects of the theory of economic growth. Their analysis of the key positions of neoclassical theory, endogenous approach and theory of evolutionary growth indicated the conclusion that these approaches agree in the fact that the category of technological change is a key generator of economic growth. The recommendations of this research can be of special benefit to decision makers on economic growth and development in the knowledge economy (Sredojević et al, 2016).

In his work, Etro has improved Romer's model of endogenous technological progress with a general production function. Under imperfect substitutability, the economy can converge to a stable state by copying the properties of neoclassical growth due to reduced marginal profitability of innovations or constant growth of linear population growth in semi-endogenous growth models (Etro, 2019).

In their work, Sokolov-Mladenović and his associates investigated the impact of research and development costs on economic growth in the EU28 in the period 20022012. To this end, they constructed a multiple regression model, which showed that, ceteris paribus, an increase in R\&D expenditure as a percentage of GDP by $1 \%$ would cause an increase in the real GDP growth rate by $2.2 \%$. This model takes into account the current financial crises and emphasizes the negative impact of the fertility rate in the EU28 on economic growth (Sokolov-Mladenović et al, 2016).

In endogenous theories of growth, with endogenous technology and its inclusion in the model, new technologies produced by individuals equipped with the knowledge, skills, and experience to use this technology were considered as investments in the human capital of countries. In their study by Boztosun et al., Basic approaches to human capital were initially theoretically explored. Then, the relations between 
human capital and economic growth were analyzed with cointegration and causality tests using data from Turkey for the period 1961-2011. Their results revealed a twofold link between the causality of human capital and economic growth variables (Boztosun et al, 2016).

In his work, McDonnell focuses on sustainable and inclusive long-term economic growth. The basic in this work is that knowledge and new ideas manifest as "innovation" and they are the key to sustainable long-term economic growth. After the main discussion, it was exposed through high-level implications to help policy makers (McDonnell, 2018).

As already mentioned in relation to Romer's growth model, it represents a fully defined model of long-term growth in which knowledge is assumed to be an input in production that has increased marginal productivity. It is basically a competitive model of equilibrium with endogenous technological changes. Unlike models based on diminishing returns, Romer explains that growth rates can increase over time by the actions of private agents, and large countries can always grow faster than small countries (Romer, 1986).

In his second paper, Romer describes earlier works that converged under the title "endogenous growth". One version, which is primarily empirical, raises the question of whether there is a general tendency for poor countries to capture rich countries. The second version, which is primarily theoretical, raises the question of what modifications are necessary to build a theory of aggregate growth that takes the economy of discovery, innovation, and technological change seriously. The article argues that the second part of the work will ultimately have a more significant impact on understanding growth (Romer, 1994).

In the third paper, he believes that developed economies and economic integration can cause a steady increase in world growth rates. Starting from the position of isolation, closer integration can be achieved by increasing trade in goods or by increasing the flow of ideas. He considered two models with different specifications of the research and development sector that represent a source of growth. Any form of integration can increase the long-term growth rate if it encourages the global exploitation of growing returns on a scale in the R\&D sector (Romer, 1991).

\section{Research Methodology}

As part of the research, a hypothesis was set as:

H0: Technological progress, based on sectors of knowledge-based services, leads to accelerated, long-term economic growth in $B \& H$. 
In addition to the main hypothesis, two auxiliary hypotheses were set as:

H1: Better labor allocation leads to higher economic growth rates

H2: Higher employment in the sectors of knowledge-based services, with limited resources, leads to accelerated economic growth in $B \& H$.

For the purposes of the research, secondary data were collected for the analysis and structure of economic growth in $\mathrm{B} \& \mathrm{H}$, in the period 2008 - 2019, according to the production and income approach and activities. The time series includes 48 quarterly values of GDP at current prices. For the purpose of this paper, activities are specifically grouped into labour-intensive, knowledge-based services, personal and social services, and other sectors.

The group of labour-intensive activities includes: Manufacturing (C), Construction $(\mathrm{F})$, Wholesale and retail trade $(\mathrm{G})$ and Transport and storage $(\mathrm{H})$, Accommodation and food service activities (I), Arts, entertainment and Recreation (R) and Other service activities (S).

The group of knowledge-based activities includes: ICT services (J) and Financial and insurance activities $(\mathrm{K})$.

The group of social services includes: Professional, scientific and scientific activities (M), Administrative and support service activities (N), Public administration and defense $(\mathrm{O})$, Education $(\mathrm{P})$ and Health and social work $(\mathrm{Q})$.

The segment of other activities includes: Agriculture (A), Mining and quarrying (B), Production and supply of electricity and gas (D) and Water supply and sewerage (E).

Real estate (L) is not part of the research, due to the high level of input rent, which cannot be separated through data on gross value added, which gives an unrealistically high contribution per worker.

The agriculture segment (A) has also been placed in the category of other sectors, due to the very low level of registered workers working in this sector, which shifts the contribution of occasionally hired workers to the registered ones, artificially raising the contribution per worker.

In order to investigate the relationship between groups of knowledge-based activities, which are generators of technological progress and GDP and contributions to economic growth, the method of linear regression was used. The created model tested the assumptions of Romer's model, such as labour allocation, for activities with lower gross value added compared to others with higher contribution and monitoring of effects on GDP, and increase of employment in knowledge-based sectors, with other conditions unchanged. 


\section{Research Results}

Two settings of Romer's growth model relate to labour allocation and resource constraint. The derived formula for calculating the output per worker is:

$$
y_{t}=\overline{A_{0}}(1-\bar{l})(1+\bar{g})^{t}
$$

where is $\mathrm{y}_{\mathrm{t}}$ - output per worker, $\overline{A_{0}}$ - initial amount of knowledge, $\bar{l}$ - parameter for workers who produce ideas and $\bar{g}$ - growth rate of knowledge.

The growth rate of knowledge can be additionally written as:

$$
\bar{g}=\bar{z} \bar{l} \bar{L}
$$

where is $\bar{z}$-constant change in relation to two time periods and $\bar{L}$-total labour force. In the first case, an increase or decrease in employment in the country affects the growth rate of knowledge. If it is an increase in employment, it will immediately and steadily increase the growth rate of output per capita, so it will be $\bar{L} \rightarrow \bar{g} \rightarrow y_{t}$. In the second case, increasing the share of workers who produce ideas, assuming all other equal parameters, increases the growth rate of knowledge where,

$$
\bar{l} \rightarrow \bar{g} \rightarrow y_{t} \text {, ali i } \bar{l} \rightarrow y_{t}
$$

The results of the conducted research confirm these assumptions.

Available data from the Agency for Statistics of B\&H are grouped by activities, of which there are a total of 19 , according to the quarterly values of gross value added of each sector, in current prices. In the second phase of statistical processing, data for activities are grouped into four groups: labour-intensive, knowledge-based services, personal and social services, and other sectors.

Table 1 in the appendix shows the grouped results according to these groups, noting that the results are not included for the Real Estate (L) sector, FISIM, which includes financial intermediation services indirectly measured, and the column "Taxes less subsidies", that would ultimately show the exact sum of the lines shown for calculating the quarterly GDP.

For comparison, Table 2 from the appendix shows the number of employed persons according to the observed groups. The difference appears in the time series due to different methodologies in the records of the number of employees by sectors before 2013. Since 2013, the methodology of employee records by sectors has been harmonized with the methodology for gross value-added records. Data from Table 2 and Chart 1, show share of employees in labour-intensive activities in relation to the total number of employees, increasing share from $52 \%$ to $58 \%$, while the share of employees in the segment of personal and social services decreased from $33 \%$ to $29 \%$. The share of employees in the segment of knowledge-based services remained the same at $5 \%$. 
Graph 1: Share of employees by groups

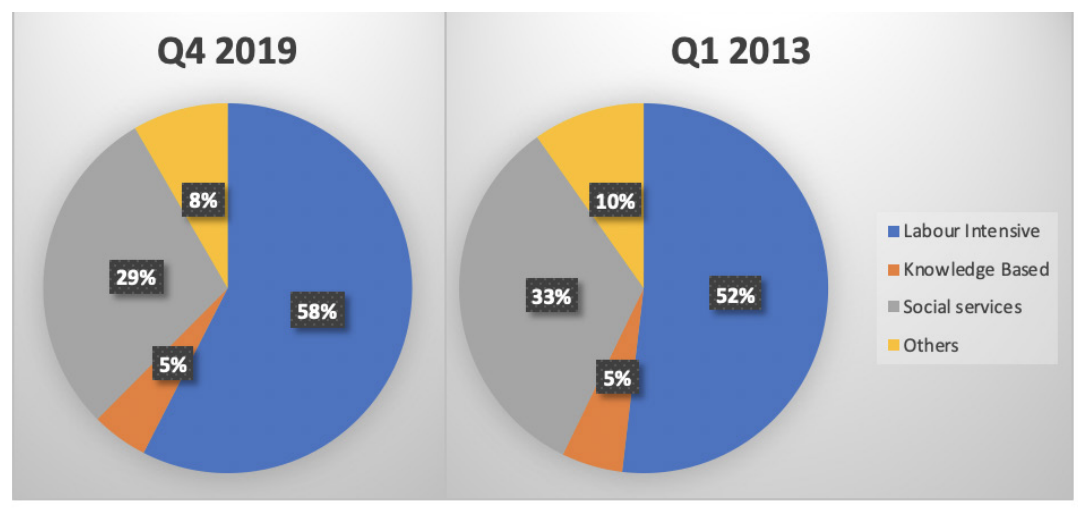

Source: Own creation

In order to estimate the exact contribution of workers in gross value added according to the observed groups, the calculation shown in Table 3 was made. The data include a time series of 28 quarterly values, due to methodological differences in data processing before 2013. According to the analysed data, the sectors of knowledge-based services make the largest contribution in relation to the sectors of employees in labour-intensive activities and personal and social services. The "other" sector is not relevant for this analysis due to previously inadequate data for the agricultural sector, which is part of this segment. The average value of data for these each of these three segments, if put in relation to the sectors of knowledge-based services, shows that a worker employed in the sector of knowledge-based services has a 2.5 higher contribution compared to a worker in the sectors of labour-intensive activities and 2.47 higher contribution compared to one worker in the segment of personal and social services. This proves the second setting of Romero's model of labour allocation, where one worker allocated from the labour-intensive sector or personal and social services to the knowledge-based services sectors would contribute 2.5 through output per worker, which would improve faster allocation of economic growth, with the restriction that it is possible to train workers for new jobs.

From Table 3, shown in the appendix, it can also be seen that the contribution of workers in the knowledge-based services sectors is 1.71 higher than the average contribution of all workers in terms of gross value added. The data from Table 3 are shown in Graph 2. As can be seen in the graph, the sector of personal and social services has a linear trend, in contrast to the sector of labour-intensive activities where the impact of seasonal trends is seen, which ultimately applies to total GDP. The knowledge-based services sector mostly shows a steady and raising contribution. 
Graph 2: Gross quarterly contribution per worker by observed sectors

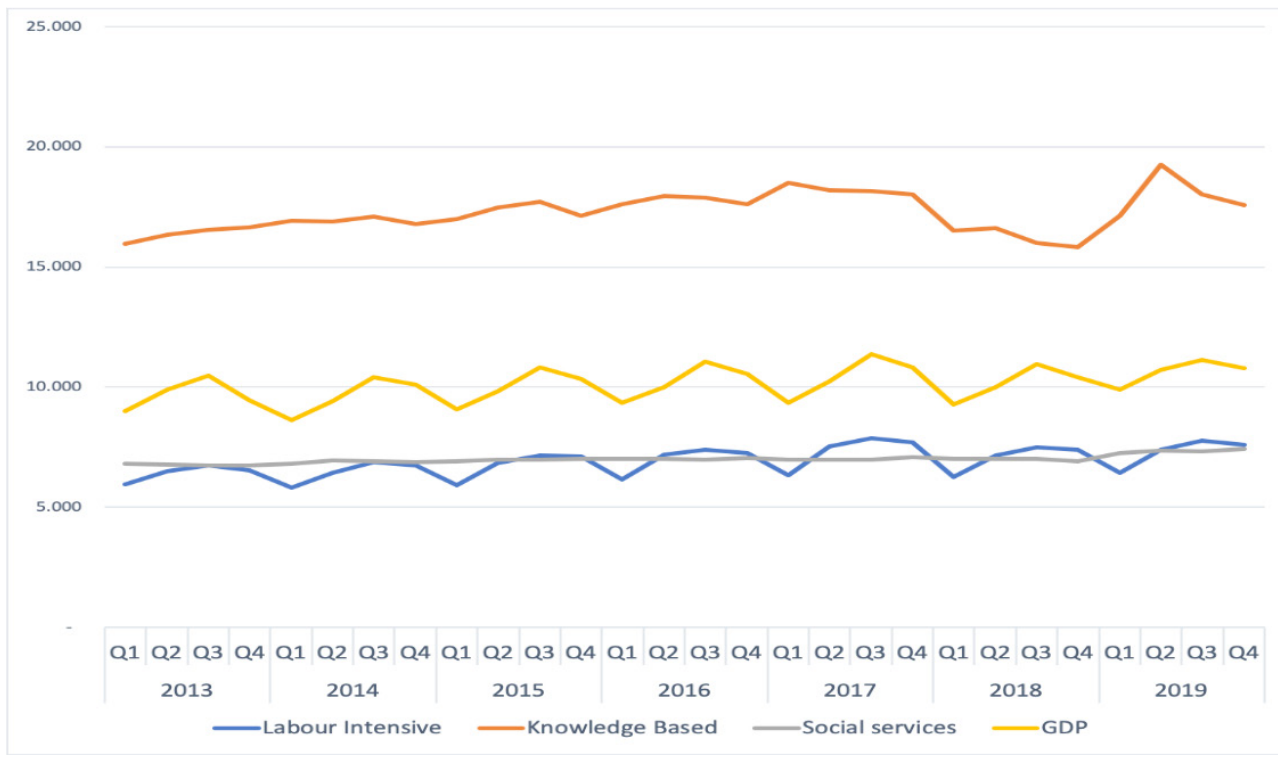

Source: Own creation

In order to examine the relationship between GDP and the knowledge-based services sector, as well as the contribution of this sector, a linear regression model was used, which includes 48 quarterly values for the knowledge-based services sector and GDP. In this model, the dependent variable is GDP, and the independent sector is knowledge-based services. The results were statistically processed in Python and are shown in Table 4.

Table 1: Display the results of regression analysis

OLS Regression Results

\begin{tabular}{|c|c|c|c|c|}
\hline Dep. Variable: & GDP & R-squared: & \multicolumn{2}{|r|}{0.705} \\
\hline Model: & OLS & Adj. R-squared: & & 0.699 \\
\hline Method: & Least Squares & F-statistic: & \multicolumn{2}{|r|}{110.0} \\
\hline Date: & Fri, 19 Jun 2020 & Prob (F-statistic): & & $30 e-14$ \\
\hline Time: & $07: 47: 31$ & Log-Likelihood: & \multicolumn{2}{|c|}{-700.63} \\
\hline No. Observations & 48 & AIC: & \multicolumn{2}{|c|}{1405 . } \\
\hline Df Residuals: & 46 & BIC: & \multicolumn{2}{|r|}{1409.} \\
\hline Df Model: & 1 & \\
\hline \multicolumn{5}{|c|}{$\begin{array}{l}\text { Covariance Type: } \\
\text { nonrobust }\end{array}$} \\
\hline & std err & $P>|t|$ & {$[0.025$} & $0.975]$ \\
\hline const & $-8.746 e+05$ & -1.156 & $-2.4 e+06$ & $6.48 e+05$ \\
\hline Knowledge Based & 13.5739 & 10.486 & 10.968 & 16.179 \\
\hline \multicolumn{5}{|c|}{ 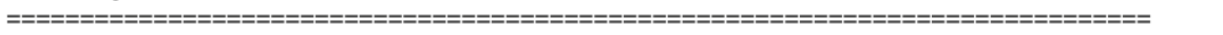 } \\
\hline Omnibus: & 1.195 & Durbin-Watson: & \multicolumn{2}{|r|}{1.615} \\
\hline Prob(Omnibus): & 0.550 & Jarque-Bera (JB): & \multicolumn{2}{|r|}{1.222} \\
\hline Skew: & 0.329 & $\operatorname{Prob}(J B):$ & \multicolumn{2}{|r|}{0.543} \\
\hline Kurtosis: & 2.579 & Cond. No. & \multicolumn{2}{|c|}{$5.67 e+06$} \\
\hline
\end{tabular}


The results from the table show that there is a strong relationship between the dependent and the independent variable. The value of the coefficient R2 is 0.705 , which shows that our model can explain the efficiency of $70.5 \%$ or that $70.5 \%$ of GDP growth can be explained by the growth of the knowledge-based services sector. A p-value of 0.000 for the coefficient of the knowledge-based services sector implies that the impact of the knowledge-based services sector on GDP is statistically significant.

Based on data from statistical processing, the model formula is defined:

$$
\text { GDP }=-874.600+13,5739 * \text { Knowledge Based }
$$

In Graph 3, the defined model and the relationship between the dependent and independent variables are graphically shown.

Graph 3: Graphical representation of the defined model
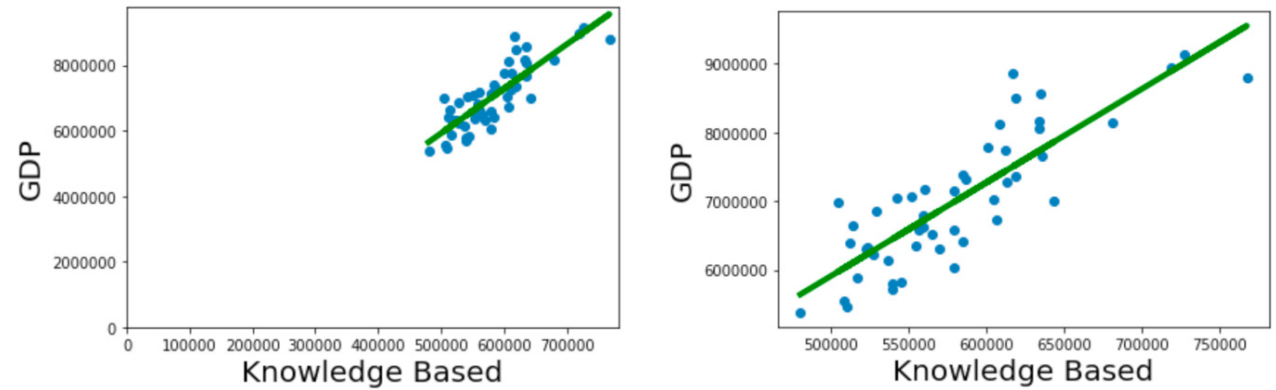

Source: Own creation

Based on the created model of linear regression between the knowledge-based services sector and GDP, the first assumption of Romero's growth-related growth model will be tested.

In the resource constraint assumption, we saw that an increase in employment leads to an increase in the growth rate of knowledge, and that to an increase in output (). Assuming that the number of employees increased by 1,000 over four quarters, we will get the gross contribution of the knowledge-based sector as shown in Table 5. On the left side of the table, the quarterly value of the knowledge-based service sector is calculated where the number of employees is multiplied by the average gross contributions per worker. According to the created model of linear regression, based on these values, the GDP projection was made. In the right part of the table, the data for the previous period and the difference are shown. 
Table 5: Projections of GDP trends with employment growth

\begin{tabular}{|c|c|c|c|c|c|}
\hline Period & $\begin{array}{l}\text { Knowledge } \\
\text { based (000) }\end{array}$ & GDP (000) & Period & GDP (t-1) (000) & Difference (000) \\
\hline Q1 & 723.672 & 8.948 .449 & Q1 & 8.141 .927 & 806.522 \\
\hline Q2 & 740.932 & 9.182 .738 & Q2 & 8.788 .384 & 394.354 \\
\hline Q3 & 758.192 & 9.417 .028 & Q3 & 9.144 .032 & 272.996 \\
\hline Q4 & 775.453 & 9.651 .317 & $\mathrm{Q} 4$ & 8.951 .253 & 700.064 \\
\hline TOT & & 37.199.532 & & 35.025.596 & 2.173.936 \\
\hline
\end{tabular}

Source: Author's creation based on projections

The overall difference shows that increasing employment in the knowledge-based services sectors leads to accelerated economic growth and that investing in these sectors leads to higher returns. On this basis alone, based on the data in Table 5, an economic growth rate of $6.21 \%$ per year would be achieved, proving the first assumption that resource constraints, and in our case, new employment in knowledge-based segments, lead to faster economic growth.

By proving the first and second postulates of the Romero model, it is proven that technological progress, through better work allocation and higher employment within the knowledge-based services sector, also leads to accelerated rates of economic growth.

\section{CONCLUSIONS AND RECOMMENDATIONS}

In the structure of gross domestic product, the highest absolute gross value added is created by the sectors of labour-intensive activities. These sectors also employ the largest number of workers, $58 \%$ of all employees at the end of 2019.

The average value of gross value added per worker shows that a worker employed in the sectors of knowledge-based services has a 2.5 higher contribution compared to a worker in the labour-intensive sectors and a 2.47 higher contribution compared to one worker in the personal and social services segment.

The contribution of workers in the knowledge-based services sectors is 1.71 higher than the average contribution of all workers in terms of gross value added.

The created regression analysis model shows that there is a strong relationship between the dependent variable of GDP and the independent variable of the Knowledge-Based Services Sector.

Tests of the implemented model show that additional employment in the sectors of knowledge-based services leads to accelerated economic growth in B\&H. 
Since, worker employed in the sectors of knowledge-based services has higher contributions compared to other workers employed in the other sectors. Thus, implementing economic policy measures that would stimulate employing those workers that contribute more, which would lead to higher economic growth rates should be considered.

Economic policy measures should stimulate investing in technological progress through fiscal policy, including lower tax rates for companies.

Companies, from the sectors of knowledge-based services, that contribute more to the economic growth, should have higher incentives from the policy makers, through direct and indirect measures.

\section{REFERENCE}

1. Azam, M. and Ahmed, A.M., 2015. Role of human capital and foreign direct investment in promoting economic growth. International Journal of Social Economics.

2. Basile, R. and Usai, S., 2015. Analysis of regional endogenous growth. In Handbook of research methods and applications in economic geography. Edward Elgar Publishing.

3. Bond-Smith, S., McCann, P. and Oxley, L., 2018. A regional model of endogenous growth without scale assumptions. Spatial Economic Analysis, 13(1), pp.5-35.

4. Boztosun, D., Aksoylu, S. and Şentürk Ulucak, Z., 2016. The role of human capital in economic growth. Economics World, 4(3), pp.101-110.

5. Bondarev, A. and Greiner, A., 2017. Endogenous growth and structural change through vertical and horizontal innovations. Macroeconomic Dynamics, pp.128.

6. Choi, C. and Yi, M.H., 2018. The Internet, R\&D expenditure and economic growth. Applied Economics Letters, 25(4), pp.264-267.

7. Collins, T., 2015. Imitation: A catalyst for innovation and endogenous growth. Economic Modelling, 51, pp.299-307.

8. Cozzi, G., 2017. Endogenous growth, semi-endogenous growth... or both? A simple hybrid model. Economics Letters, 154, pp.28-30.

9. Cvetanović, S., Filipović, M., Nikolić, M. and Belović, D., 2015. Endogenous growth theory and regional development policy. Spatium, pp.10-17. 
10. Day, C., 2016. Non-Scale Endogenous Growth with R\&D and Human Capital. Scottish Journal of Political Economy, 63(5), pp.443-467.

11. De, S., 2014. Intangible capital and growth in the 'new economy': Implications of a multi-sector endogenous growth model. Structural Change and Economic Dynamics, 28, pp.25-42.

12. Etro, F., 2019. The Romer Model with Monopolistic Competition and General Technology (No. wp2019_08. rdf). Universita'degli Studi di Firenze, Dipartimento di Scienze per l'Economia e l'Impresa.

13. Furukawa, Y., 2016. Innovation through Global Collaboration in an Endogenous Growth Model.

14. Ghiglino, C., Nishimura, K. and Venditti, A., 2018. Non-Balanced Endogenous Growth and Structural Change: When Romer Meets Kaldor and Kuznets.

15. Ghio, N., Guerini, M., Lehmann, E.E. and Rossi-Lamastra, C., 2015. The emergence of the knowledge spillover theory of entrepreneurship. Small Business Economics, 44(1), pp.1-18.

16. Gutiérrez, P.J., 2015. A full test of a Romer's endogenous growth model. International Journal of Economics and Business Research, 10(4), pp.297-325.

17. He, S., 2018. Endogenous Growth: Innovation, Credit Constraints, and Stock Price Bubbles.

18. Hori, T., 2017. Monetary policy, financial frictions, and heterogeneous R\&D firms in an endogenous growth model. The Scandinavian Journal of Economics.

19. Huggins, R. and Thompson, P., 2015. Entrepreneurship, innovation and regional growth: a network theory. Small Business Economics, 45(1), pp.103-128.

20. Inekwe, J.N., 2015. The contribution of R\&D expenditure to economic growth in developing economies. Social indicators research, 124(3), pp.727-745.

21. Jerbashian, V., 2016. Knowledge licensing in a model of R\&D-driven endogenous growth. The BE Journal of Macroeconomics, 16(2), pp.555-579.

22. Jones, C.I., 2019. Paul Romer: Ideas, nonrivalry, and endogenous growth. The Scandinavian Journal of Economics, 121(3), pp.859-883.

23. Kaldor, N., 1954. The relation of economic growth and cyclical fluctuations. The Economic Journal, 64(253), pp.53-71.

24. Kaldor, N., 1955. Alternative theories of distribution. The review of economic studies, 23(2), pp.83-100. 
25. Kaldor, N., 1957. A model of economic growth. The economic journal, 67(268), pp.591-624.

26. Kaldor, N. and Mirrlees, J.A., 1962. A new model of economic growth. The Review of Economic Studies, 29(3), pp.174-192.

27. Kanđija, V., Lovrić, Lj., 2007. Ekonomski rast tranzicijskih zemalja u procesu globalizacije. Research gate.

28. Kuwahara, S., 2019. Multiplicity and stagnation under the Romer model with increasing returns of R\&D. Economic Modelling, 79, pp.86-97.

29. Lucas Jr, R.E. and Moll, B., 2014. Knowledge growth and the allocation of time. Journal of Political Economy, 122(1), pp.1-51.

30. McDonnell, T., 2018. Innovation and Growth: Concepts and Policy Implications.

31. Moore, D., Vamvakidis, A., 2008. Ekonomski rast u Hrvatskoj: mogućnosti i ograničenja. Financijska teorija i praksa, Vol. 32., No. 1. pp.1-28.

32. Parente, S., 2001. The failure of endogenous growth. Knowledge, technology \& policy, 13(4), pp.49-58.

33. Pece, A.M., Simona, O.E.O. and Salisteanu, F., 2015. Innovation and economic growth: An empirical analysis for CEE countries. Procedia Economics and Finance, 26, pp.461-467.

34. Pradhan, R.P., Arvin, M.B., Hall, J.H. and Nair, M., 2016. Innovation, financial development and economic growth in Eurozone countries. Applied Economics Letters, 23(16), pp.1141-1144.

35. Qian, T., 2018. A note on the effect of patents in endogenous growth models. Applied Economics Letters, 25(3), pp.158-161.

36. Romer, P.M., 1986. Increasing returns and long-run growth. Journal of political economy, 94(5), pp.1002-1037.

37. Romer, P.M., 1994. The origins of endogenous growth. Journal of Economic perspectives, 8(1), pp.3-22.

38. Romer, P.M., 1989. Human capital and growth: theory and evidence (No. w3173). National Bureau of Economic Research.

39. Romer, P.M., 2015. Mathiness in the theory of economic growth. American Economic Review, 105(5), pp.89-93. 
40. Sokolov-Mladenović, S., Cvetanović, S. and Mladenović, I., 2016. R\&D expenditure and economic growth: EU28 evidence for the period 2002-2012. Economic research-Ekonomska istraživanja, 29(1), pp.1005-1020.

41. Sredojević, D., Cvetanović, S. and Bošković, G., 2016. Technological changes in economic growth theory: Neoclassical, endogenous, and evolutionary-institutional approach. Economic Themes, 54(2), pp.177-194.

42. Stevanović, S., 2019. Model ekonomskog rasta u Bosni i Hercegovini u periodu 2007-2017 godine - Mogućnosti za umanjenje budućih rizika. Research gate.

43. Swan, T.W., 1956. Economic growth and capital accumulation. Economic record, 32(2), pp.334-361.

44. Wang, F. and Liu, M., 2018, February. Analysis on the Contribution of R\&D Input to Economic Growth in Western China. In 2nd International Forum on Management, Education and Information Technology Application (IFMEITA 2017). Atlantis Press.

45. Zhao, R., 2019. Technology and economic growth: From Robert Solow to Paul Romer. Human Behavior and Emerging Technologies, 1(1), pp.62-65.

46. Zhong, L., 2017. Innovation as Determinants of Economic Growth in US Counties. Journal of Applied Business and Economics, 19(4). 


\section{ZNAČAJ TEHNOLOŠKOG NAPRETKA U MJERENJU EKONOMSKOG RASTA U BOSNI I HERCEGOVINI}

\section{SAŽETAK}

Ekonomski rast predstavlja jedan od najvažnijih pojmova u svjetskoj ekonomiji. Iako neki autori kritički smatraju da nivo i stope ekonomskog rasta nužno ne prikazuju stvarni nivo životnog standarda, on ipak ostaje glavni način za mjerenje blagostanja jedne zemlje. Različiti pogledi na temu ekonomskog rasta, kao i faktori koji na njega utiču, prisutni su kroz historiju ekonomske misli od samih početaka.

Za razliku od mnogih teorija ekonomskog rasta, koje smatraju da će dugoročno doći do opadajućih prinosa na angažirane faktore proizvodnje poput rada i kapitala, Paul Romer u svojoj teoriji endogenog rasta smatra da tehnološki napredak, putem akumulacije znanja, stvaranja ideja i inovacija, dovodi do rastućih prinosa, a time doprinosi više dugoročnom ekonomskom rastu, za razliku od drugih faktora.

U radu se, na primjeru ekonomskog rasta u BiH testirala hipoteza da djelatnosti usluga baziranih na znanju doprinose više bruto domaćem proizvodu, u odnosu na druge sektore. Za dokazivanje hipoteze, napravljen je i testiran model višestruke linearne regresije zasnovan na vremenskoj seriji od 48 uzastopnih kvartalnih vrijednosti bruto domaćeg proizvoda BiH i sektorske bruto dodane vrijednosti prema dohodovnom i proizvodnom pristupu. U modelu su djelatnosti grupisane na one koje su pretežno radno intenzivne, usluge bazirane na znanju, osobne i socijalne usluge, te ostale djelatnosti.

Rezultati su pokazali da prosječna vrijednost bruto dodate vrijednosti po radniku zaposlenom u sektorima usluga zasnovanih na znanju ima 2,5 veći doprinos u odnosu na radnika u radno intenzivnim sektorima i 2,47 veći doprinos u odnosu na jednog radnika sektoru ličnih i socijalnih usluga. Također, testovi definisanog modela pokazuju da dodatno zapošljavanje u sektorima usluga zasnovanih na znanju dovodi do ubrzanog ekonomskog rasta u BiH.

Ključne riječi: Ekonomski rast, Tehnološki napredak, BDP, Romerov model, Endogene teorije rasta.

JEL: O32, 047. 


\section{APPENDIX}

Table 1: Gross value added by grouped sectors

\begin{tabular}{|c|c|c|c|c|c|c|}
\hline \multicolumn{2}{|c|}{$\mathrm{KM}$ in 000} & \multirow{2}{*}{$\begin{array}{c}\text { Labour Intensive } \\
1.910 .244\end{array}$} & \multirow{2}{*}{$\begin{array}{c}\begin{array}{c}\text { Knowledge } \\
\text { Based }\end{array} \\
480.190\end{array}$} & \multirow{2}{*}{$\begin{array}{c}\text { Social services } \\
1.216 .135\end{array}$} & \multirow{2}{*}{$\begin{array}{l}\text { Others } \\
580.429\end{array}$} & \multirow{2}{*}{$\begin{array}{c}\text { GDP } \\
.382 .819\end{array}$} \\
\hline \multirow{3}{*}{ ஓ્సે } & Q1 & & & & & \\
\hline & Q2 & 2.276 .212 & 512.492 & 1.29 & 86 & 0 \\
\hline & Q3 & 2.46 & 50 & 1.3 & 96 & 6.9 \\
\hline \multirow{5}{*}{ 오ํ } & Q4 & 2.33 & 26 & 1.3 & 94 & 6.2 \\
\hline & Q1 & 1.82 & 509.8 & 1.3 & 45 & 827 \\
\hline & Q2 & 2.201 . & 522 & 1.3 & 87 & 273 \\
\hline & Q3 & 2.32 & 513.850 & 1.31 & 1.798 & 6.63 \\
\hline & Q4 & 2.184 .182 & 516.434 & 1.33 & 1.173 & 5.8 \\
\hline \multirow{4}{*}{ 을 } & Q1 & 1.8 & & 1.3 & & 792 \\
\hline & Q2 & 2.247 .388 & 523 & 1.37 & 1.47 & .389 \\
\hline & Q3 & 2.361 .687 & 528.885 & 1.34 & 1.912 & 6.86 \\
\hline & Q4 & 2.25 & & 1.3 & 1.2 & 6.1 \\
\hline \multirow{4}{*}{ 쿨 } & Q1 & 1.92 & & 1.41 & & 5.79 \\
\hline & Q2 & 2.310 & 559 & 1.44 & 1.5 & 6.63 \\
\hline & Q3 & 2.408 & 542.329 & 1.42 & 1.88 & 7.04 \\
\hline & Q4 & 2.30 & 56 & 1.4 & 1 & 6.2 \\
\hline \multirow{4}{*}{ 곡 } & Q1 & 1.877 .670 & 53 & 1.44 & 1.0 & 5.7 \\
\hline & Q2 & 2.304 .153 & 556.092 & 1.45 & 1.494 .817 & 6.592 .302 \\
\hline & Q3 & 2.454 .133 & 551 & 1.43 & 1.81 & 7.076 .689 \\
\hline & Q4 & 2.303 .205 & & 1.446 & 1.221 .089 & 6.354 .164 \\
\hline \multirow{4}{*}{  } & Q1 & 1.972 .634 & 545. & 1.43 & 1.201 .297 & 5.827 .399 \\
\hline & Q2 & 2.381 .152 & 559.408 & 1.432 & 1.676 .199 & 6.795 .576 \\
\hline & Q3 & 2.457 .621 & 559.937 & 1.428 .669 & 1.925 .281 & 7.162 .858 \\
\hline & Q4 & 2.399 .535 & 565.297 & 1.450 .1 & 1.313 .192 & 6.510 .955 \\
\hline
\end{tabular}

\begin{tabular}{|c|c|c|c|c|c|c|}
\hline \multicolumn{2}{|c|}{ KM in 000} & Labour Intensive & Knowledge Based & Social services & Others & \multirow{2}{*}{$\begin{array}{c}\text { GDP } \\
6.034 .659\end{array}$} \\
\hline \multirow{3}{*}{$\overrightarrow{\bar{d}}$} & Q1 & 2.209 .911 & 5 & 1.467 .695 & 758.223 & \\
\hline & Q2 & 2.463 .440 & 79.262 & 1.506 .709 & 27 & .583 .476 \\
\hline & Q3 & 2.651 .497 & 586.928 & 1.495 .591 & 1.122 .294 & 7.325 .954 \\
\hline \multirow{4}{*}{ 孚 } & Q4 & 2.598 .674 & 579.535 & 1.519 .333 & 1.002 .573 & 7.144 .621 \\
\hline & Q1 & 2.262 .873 & 584.468 & 1.535 .209 & 731.731 & 6.424 .738 \\
\hline & Q2 & 2.669 .720 & 605.198 & 1.54 & 79 & 7.025 .453 \\
\hline & Q3 & 2.813 .130 & 612.198 & 1.543 .822 & 1.244 .769 & 7.745 .121 \\
\hline \multirow{5}{*}{ ํㅜㄹ } & Q4 & 2.802 .880 & 584.668 & 1.549 .338 & 994.147 & 7.393 .741 \\
\hline & Q1 & 2.44 & & 1.5 & 78 & 6.73 \\
\hline & Q2 & 2.900 .830 & 613.088 & 1.560 .061 & 746.953 & 7.269 .276 \\
\hline & Q3 & 3.012 .337 & 608.145 & 1.553 .807 & 1.347 .322 & 8.119 .294 \\
\hline & Q4 & 2.96 & 600.594 & 1.57 & 1.08 & 7.77 \\
\hline \multirow{4}{*}{ 곡 } & Q1 & 2.66 & & 1.5 & & 7.00 \\
\hline & Q2 & 3.148 .077 & 636.005 & 1.579 .592 & 771.314 & 7.654 .644 \\
\hline & Q3 & 3.330 .673 & 635.311 & 1.568 .250 & 1.344 .481 & 8.562 .294 \\
\hline & Q4 & 3.2 & 633.630 & 1.59 & 1.0 & 8.156 .294 \\
\hline \multirow{4}{*}{ 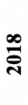 } & Q1 & 2.855 .670 & .472 & 1.61 & 785 & 7.361 .515 \\
\hline & Q2 & 3.313 .908 & 634.341 & 1.624 .933 & 878.940 & 8.052 .805 \\
\hline & Q3 & 3.464 .462 & 617.272 & 1.632 .025 & 1.418 .728 & 8.869 .087 \\
\hline & Q4 & 3.431 .953 & 618.911 & 1.667 .054 & 1.093 .633 & 8.494 .997 \\
\hline \multirow{4}{*}{$\stackrel{\circ}{\overline{\check{c}}}$} & Q1 & 3.014 .590 & 680.970 & 1.730 .260 & 1.098 .881 & 8.141 .927 \\
\hline & Q2 & 3.469 .722 & 768.056 & 1.747 .490 & 1.080 .161 & 8.788 .384 \\
\hline & Q3 & 3.646 .333 & 727.422 & 1.742 .915 & 1.249 .536 & 9.144 .032 \\
\hline & Q4 & 3.606 .545 & 719.454 & 1.786.174 & 1.191 .166 & 8.951 .253 \\
\hline
\end{tabular}

Source: Statistical agency of Bosnia and Herzegovina

Table 2: Employees by groups

\begin{tabular}{|c|c|c|c|c|c|c|c|c|c|c|c|c|c|}
\hline \multicolumn{2}{|c|}{ Period } & \multirow{2}{*}{$\begin{array}{c}\begin{array}{c}\text { Labour } \\
\text { Intensive }\end{array} \\
331.533\end{array}$} & \multirow{2}{*}{$\begin{array}{c}\begin{array}{c}\text { Knowledge } \\
\text { Based }\end{array} \\
34.183\end{array}$} & \multirow{2}{*}{$\begin{array}{c}\text { Social services } \\
210.899\end{array}$} & \multirow{2}{*}{$\begin{array}{c}\text { Others } \\
62.600\end{array}$} & \multirow{2}{*}{$\begin{array}{c}\text { TOтAL } \\
648.421\end{array}$} & \multicolumn{2}{|c|}{ Period } & \multirow{2}{*}{$\begin{array}{c}\begin{array}{c}\text { Labour } \\
\text { Intensive }\end{array} \\
420.702\end{array}$} & \multirow{2}{*}{$\begin{array}{c}\begin{array}{c}\text { Knowledge } \\
\text { Based }\end{array} \\
34.763\end{array}$} & \multirow{2}{*}{$\begin{array}{c}\text { Social services } \\
226.435\end{array}$} & \multirow{2}{*}{$\begin{array}{c}\text { Others } \\
65.528\end{array}$} & \multirow{2}{*}{$\begin{array}{c}\text { TOTAL } \\
750.543\end{array}$} \\
\hline & Q1 & & & & & & \multirow{4}{*}{ 독 } & Q1 & & & & & \\
\hline \multirow{3}{*}{ 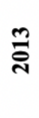 } & Q2 & 367.133 & 34.236 & 211.843 & 63.207 & 686.299 & & Q2 & 417.666 & 34.988 & 226.162 & 66.265 & 747.759 \\
\hline & Q3 & 365.619 & 33.859 & 211.688 & 63.779 & 683.645 & & Q3 & 423.598 & 34.994 & 225.113 & 67.030 & 753.439 \\
\hline & Q4 & 367.411 & 33.962 & 215.092 & 63.413 & 689.270 & & Q4 & 423.290 & 35.142 & 225.831 & 66.597 & 753.202 \\
\hline \multirow{4}{*}{ 록 } & Q1 & 380.564 & 34.218 & 215.502 & 64.297 & 700.667 & \multirow{4}{*}{ 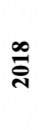 } & Q1 & 455.604 & 37.488 & 230.770 & 67.167 & 794.505 \\
\hline & Q2 & 382.769 & 34.292 & 216.609 & 64.787 & 700.659 & & Q2 & 462.948 & 38.208 & 232.144 & 69.163 & 806.031 \\
\hline & Q3 & 386.560 & 34.366 & 216.143 & 65.500 & 704.724 & & Q3 & 463.430 & 38.613 & 233.237 & 69.763 & 808.627 \\
\hline & Q4 & 384.907 & 34.532 & 220.821 & 65.259 & 707.725 & & Q4 & 463.881 & 39.106 & 240.967 & 69.578 & 817.375 \\
\hline \multirow{4}{*}{ ฮั่ } & Q1 & 383.159 & 34.394 & 222.071 & 65.339 & 707.560 & \multirow{4}{*}{ ิㅡㄹ } & Q1 & 469.341 & 39.728 & 238.450 & 70.602 & 822.275 \\
\hline & Q2 & 390.737 & 34.644 & 221.736 & 65.005 & 714.586 & & Q2 & 469.786 & 39.860 & 237.576 & 71.013 & 821.124 \\
\hline & Q3 & 393.352 & 34.566 & 220.750 & 65.075 & 716.230 & & Q3 & 470.249 & 40.339 & 238.136 & 69.649 & 822.259 \\
\hline & Q4 & 393.439 & 34.142 & 220.623 & 64.811 & 715.425 & & Q4 & 475.450 & 40.927 & 240.986 & 69.066 & 830.383 \\
\hline \multirow{4}{*}{$\stackrel{0}{\stackrel{2}{*}}$} & Q1 & 397.727 & 34.444 & 221.721 & 65.053 & 721.633 & & & & & & & \\
\hline & Q2 & 403.127 & 34.144 & 221.985 & 66.073 & 728.121 & & & & & & & \\
\hline & Q3 & 406.973 & 34.032 & 222.412 & 66.939 & 733.261 & & & & & & & \\
\hline & Q4 & 409.932 & 34.097 & 224.620 & 66.385 & 737.954 & & & & & & & \\
\hline
\end{tabular}

Source: Statistical agency of Bosnia and Herzegovina 
Table 3: Gross quarterly contribution per worker by grouped sectors

\begin{tabular}{|c|c|c|c|c|c|c|c|c|c|c|c|c|c|}
\hline \multicolumn{2}{|c|}{ км } & \multirow{2}{*}{$\begin{array}{c}\begin{array}{c}\text { Labour } \\
\text { Intensive }\end{array} \\
5.950\end{array}$} & \multirow{2}{*}{$\begin{array}{c}\begin{array}{c}\text { Knowledge } \\
\text { Based }\end{array} \\
15.947\end{array}$} & \multirow{2}{*}{$\begin{array}{c}\begin{array}{c}\text { Social } \\
\text { services }\end{array} \\
6.799\end{array}$} & \multirow{2}{*}{$\begin{array}{l}\text { Others } \\
19.190\end{array}$} & \multirow{2}{*}{$\begin{array}{l}\text { GDP } \\
8.987\end{array}$} & \multicolumn{2}{|c|}{ KM } & \multirow{2}{*}{$\begin{array}{c}\text { Labour } \\
\text { Intensive }\end{array}$} & \multirow{2}{*}{$\begin{array}{r}\text { Knowledge Based } \\
18.508\end{array}$} & \multirow{2}{*}{$\begin{array}{c}\begin{array}{c}\text { Social } \\
\text { services }\end{array} \\
6.968\end{array}$} & \multirow{2}{*}{$\begin{array}{l}\text { Others } \\
11.016\end{array}$} & \multirow{2}{*}{$\begin{array}{l}\text { GDP } \\
9.331\end{array}$} \\
\hline \multirow{4}{*}{$\stackrel{\text { ma }}{\bar{乛}}$} & Q1 & & & & & & \multirow{3}{*}{ 곡 } & Q1 & & & & & \\
\hline & Q2 & 6.486 & 16.340 & 6.763 & 26.519 & 9.902 & & Q2 & 7.537 & 18.178 & 6.984 & 11.640 & 10.237 \\
\hline & Q3 & 6.722 & 16.537 & 6.749 & 30.187 & 10.477 & & Q3 & 7.863 & 18.155 & 6.967 & 20.058 & 11.364 \\
\hline & Q4 & 6.531 & 16.645 & 6.742 & 20.709 & 9.446 & & Q4 & 7.692 & 18.031 & 7.082 & 15.729 & 10.829 \\
\hline \multirow{4}{*}{$\stackrel{\vec{\pi}}{\vec{T}}$} & Q1 & 5.807 & 16.917 & 6.811 & 11.793 & 8.613 & \multirow{4}{*}{$\stackrel{\infty}{\stackrel{\infty}{*}}$} & Q1 & 6.268 & 16.498 & 6.997 & 11.753 & 9.266 \\
\hline & Q2 & 6.436 & 16.892 & 6.956 & 10.702 & 9.396 & & Q2 & 7.158 & 16.602 & 7.000 & 12.708 & 9.991 \\
\hline & Q3 & 6.859 & 17.079 & 6.919 & 17.134 & 10.395 & & Q3 & 7.476 & 15.986 & 6.997 & 20.336 & 10.968 \\
\hline & Q4 & 6.751 & 16.783 & 6.880 & 15.363 & 10.095 & & Q4 & 7.398 & 15.826 & 6.918 & 15.718 & 10.393 \\
\hline \multirow{4}{*}{ อี่ } & Q1 & 5.906 & 16.993 & 6.913 & 11.199 & 9.080 & \multirow{4}{*}{ 亏ें } & Q1 & 6.423 & 17.141 & 7.256 & 15.564 & 9.902 \\
\hline & Q2 & 6.833 & 17.469 & 6.979 & 12.226 & 9.832 & & Q2 & 7.386 & 19.269 & 7.355 & 15.211 & 10.703 \\
\hline & Q3 & 7.152 & 17.711 & 6.994 & 19.128 & 10.814 & & Q3 & 7.754 & 18.033 & 7.319 & 17.940 & 11.121 \\
\hline & Q4 & 7.124 & 17.125 & 7.023 & 15.339 & 10.335 & & Q4 & 7.586 & 17.579 & 7.412 & 17.247 & 10.780 \\
\hline \multirow{4}{*}{ ํㅜㄹ } & Q1 & 6.143 & 17.606 & 6.996 & 12.013 & 9.339 & & & & & & & \\
\hline & Q2 & 7.196 & 17.956 & 7.028 & 11.305 & 9.984 & & & & & & & \\
\hline & Q3 & 7.402 & 17.870 & 6.986 & 20.128 & 11.073 & & & & & & & \\
\hline & Q4 & 7.241 & 17.614 & 7.032 & 16.271 & 10.538 & & & & & & & \\
\hline
\end{tabular}

Source: Statistical agency of Bosnia and Herzegovina \& own creation 